\title{
Spatial variations of effective elastic thickness of the lithosphere in Central America and surrounding regions
}

\author{
Alberto Jiménez-Díaz , Javier Ruiz , Marta Pérez-Gussinyé , Jon F. Kirby , \\ José A. Álvarez-Gómez, Rosa Tejero , Ramón Capote
}

Keywords:

effective elastic thickness

spectral methods

lithosphere structure

Central America

Caribbean plate

\begin{abstract}
A B S T R A C T
As a proxy for long-term lithospheric strength, the effective elastic thickness $\left(T_{e}\right)$ can be used to understand the relationship between lithospheric rheology and geodynamic evolution of complex tectonic settings. Here we present, for the first time, high-resolution maps of spatial variations of $T_{e}$ in Central America and surrounding regions from the analysis of the coherence between topography and Bouguer gravity anomaly using multitaper and wavelet methods. Regardless of the technical differences between the two methods, there is a good overall agreement in the spatial variations of $T_{e}$ recovered from both methods. Although absolute $T_{e}$ values can vary in both maps, the qualitative $T_{e}$ structure and location of the main $T_{e}$ gradients are very similar. The pattern of the $T_{e}$ variations in Central America and surrounding regions agrees well with the tectonic provinces in the region, and it is closely related to major tectonic boundaries, where the Middle American and Lesser Antilles subduction zones are characterized by a band of high $T_{e}$ on the downgoing slab seaward of the trenches. These high $T_{e}$ values are related to internal loads (and in the case of the southernmost tip of the Lesser Antilles subduction zone also associated with a large amount of sediments) and should be interpreted with caution. Finally, there is a relatively good correlation, despite some uncertainties, between surface heat flow and our $T_{e}$ results for the study area. These results suggest that although this area is geologically complex, the thermal state of the lithosphere has profound influence on its strength, such that $T_{e}$ is strongly governed by thermal structure.
\end{abstract}

\section{Introduction}

The knowledge of lateral variations in lithøsphere strength can aid in understanding how surface deformation relates to deep

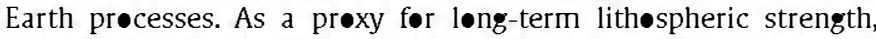

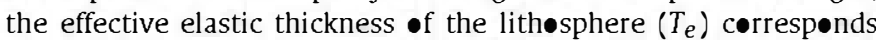
to the thickness of an idealized elastic plate bending under the same applied loads (Watts, 2001), and is related the integrated mechanical strength of the lithøsphere (Burøv and Diament, 1995). The knowledge of $T_{e}$ in different places prøvides a measurement of the spatial variation of the lithøspheric strength, which is strøngly

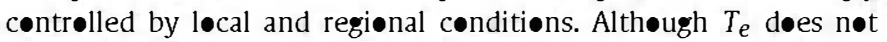
represent an actual depth the base of the mechanical lith sphere, its spatial variatiøns reflect relative lateral variatiøns in lithøspheric mechanical thickness (see McNutt, 1984). Thus it can be used to understand the relatiønship between lith spheric rhe-

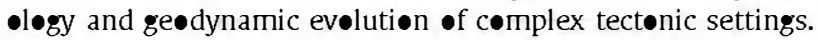

$T_{e}$ primarily depends on the thickness and structure of the crust, the compesition of the crust and the lith spheric mantle, the degree of their coupling, the thermal state of the lithosphere, the state $\bullet$ stress, plate curvature, and the presence $\bullet$ melts, fluids and faults (e.g., Lowry and Smith, 1995; Burov and Diament, 1995; Lowry et al., 2000; Watts, 2001; Artemieva, 2011). The •ceanic lithosphere generally behaves like a single mechanical layer due to the thin crust, which is usually coupled to the lithospheric

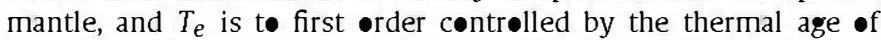
the lithøsphere at the time of løading (Watts, 2001; Kalnins and Watts, 2009). By contrast, the thermal state and rheoløical behaviør of the lith sphere in continental areas are largely a cønse-

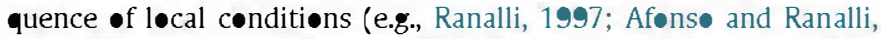
2004; Bürgmann and Dresen, 2008; Haster k and Chapman, 2011; Mareschal and Jaupart, 2013), such that there is a complex relatiønship between $T_{e}$ and its controlling parameters (Watts and Burøv, 2003; Burøv and Watts, 2006; Burøv, 2011). 


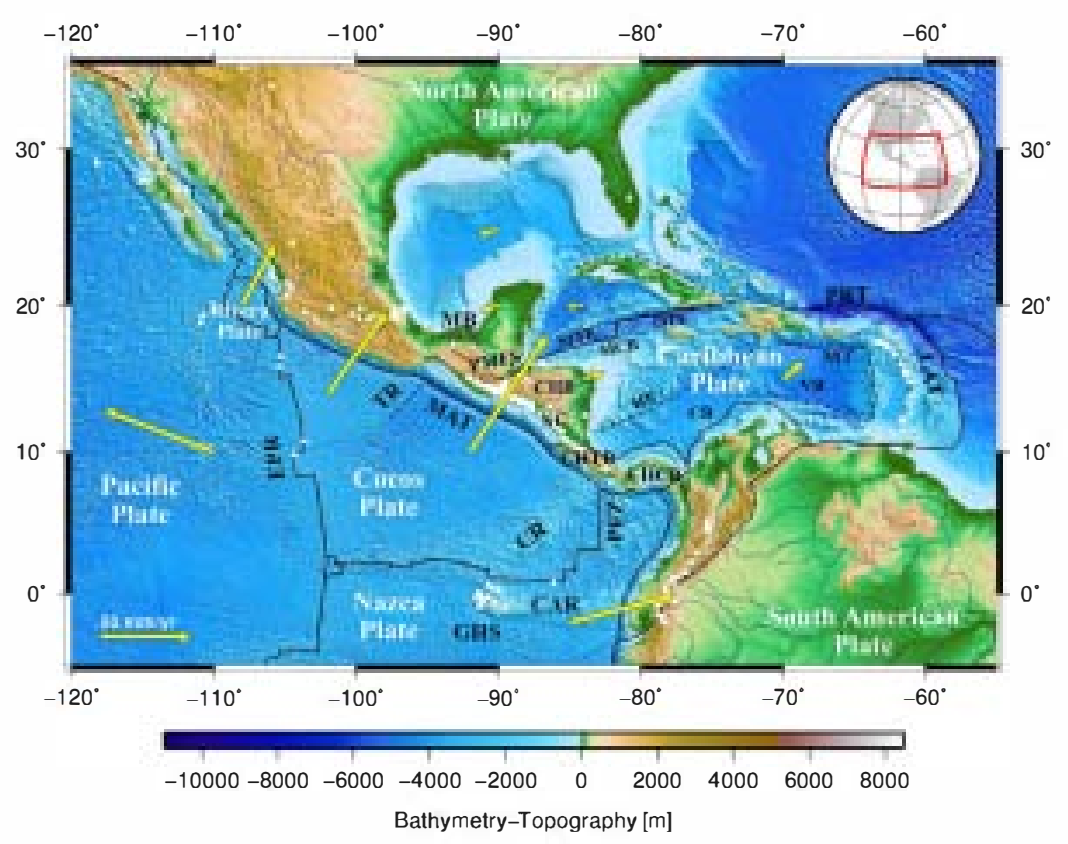

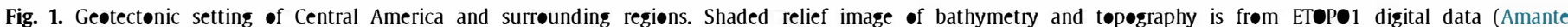

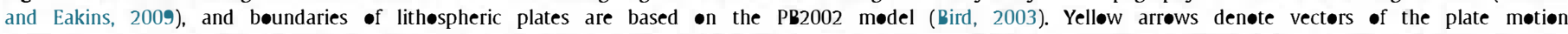

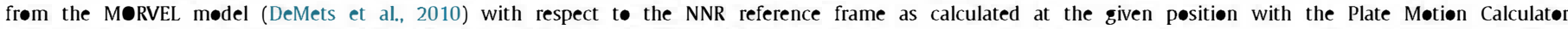

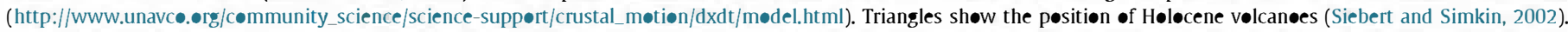

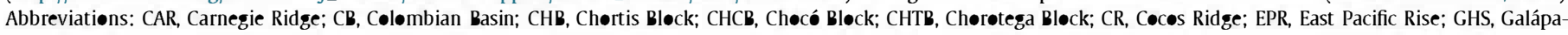

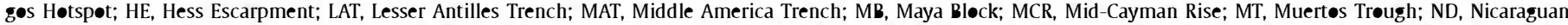

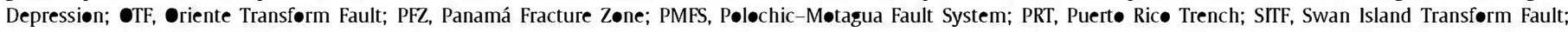

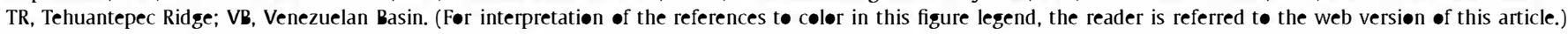

In this study we present, for the first time, high-resolution maps of spatial variations of $T_{e}$ in Central America and surrounding regions from the analysis of the Bouguer coherence using both multitaper and wavelet methods. The Central America-Caribbean region is characterized by the interaction of six lithospheric plates (Fig. 1). The Caribbean plate moves eastward relative to its two neighboring plates, North and South America plates (DeMets et al., 2010), and its perimeter is characterized by a high variability and complexity of geodynamic and tectonic processes (e.g., Sykes et al., 1982; Ross and Scotese, 1988). Therefore, this area represents a good natural laboratory to study the spatial variations of $T_{e}$, test the response of spectral methods to different factors and geodynamic conditions, and examine relationships between surface deformation, lithospheric structure and mantle dynamics.

In the following sections we first introduce the methodology and data employed for estimating $T_{e}$. We then present our results and compare them to previous estimates of $T_{e}$ in the study area. Finally, we examine the relationships between $T_{e}$ with other proxies for lithospheric and sub-lithospheric structure to improve our knowledge of the long-term rheology and mechanical behavior of the lithosphere in the study area. We also discuss how the lithospheric structure derived from our $T_{e}$ analysis relates to surface deformation.

\section{2. $T_{e}$ estimation by spectral methods}

To estimate the effective elastic thickness we calculate the coherence function relating the topography and Bouguer anomaly, commonly known as Bouguer coherence, using multitaper and wavelet methods. This function gives information on the wavelength band over which topography and Bouguer anomaly are correlated. In the coherence deconvolution method of Forsyth (1985), $T_{e}$ is estimated by comparing the observed coherence curve with coherence functions predicted for a range of $T_{e}$ values. For each given $T_{e}$, we calculate via deconvolution the initial surface and subsurface loads and compensating deflections that generate a predicted topography and gravity that best fit the observed topography and gravity anomaly, and a predicted coherence that best fits the observed coherence (Forsyth, 1985). The $T_{e}$ value that minimizes the differences between the predicted and observed quantities is the optimal one for the analyzed area. The Bouguer coherence generally tends to zero at short wavelengths, where the topography is not compensated and loads are supported predominantly by the elastic strength of the lithosphere (Forsyth, 1985). At long wavelengths, the response to loading approaches the Airy limit and the coherence tends to one. The wavelengths at which the coherence rapidly increases from 0 to 1 depend on the effective elastic thickness of the lithosphere, such that when the lithosphere is weak and $T_{e}$ is small, local compensation for loading occurs at relatively shorter wavelengths and vice versa.

In this section we describe briefly the methodology and data employed to estimate $T_{e}$. For an extensive description of the methods, choice of parameters and biases in $T_{e}$ estimation, see Supplementary Material associated with the online version of this article.

\subsection{Multitaper method}

To recover spatial variations in $T_{e}$ we divide the analysis area into overlapping windows, such that in each window the coherence is calculated and inverted assuming a spatially constant $T_{e}$, moving the centre of each window $50 \mathrm{~km}$ for each new estimate. Calculation of the observed and predicted coherence involves transformation into the Fourier domain of the topography and Bouguer gravity anomaly to estimate their auto- and crosspower spectra. Because both data sets are non-periodic and finite, the Fourier transformation presents problems of frequency leakage (Thomson, 1982; Simons et al., 2000), resulting in estimated spectra that differ from the true spectra. To reduce leakage, the data are first multiplied by a set of orthogonal tapers in the space domain, the Fourier transform of the data-taper product taken for 
each taper, and the power spectrum determined at each taper. The final estimate of the signal's true power spectrum is then the weighted average of the individual pøwer spectra $\bullet$ ver all tapers. However, the choice of taper influences the resulting power spectra and hence the coherence function (Pérez-Gussinyé et al. 2007, 2008). The set $\bullet$ f $\bullet$ rthøgnal tapers is defined by the bandwidth prøduct $N W$ that contr ls the wavelength resøtin and spectral leakage (where $N$ is the number of samples within the data windøw and $\boldsymbol{W}$ is the half bandwidth of the central løbe of the pøwer spectral density of the first- $\bullet$ rder taper) and by the number $\bullet$ tapers $K$ that governs the estimation variance (see Simons et al., 2000). The chøice of bandwidth parameter $N W$ in the multitaper technique is important. As the bandwidth increases, the reselution (i.e. the minimum separatiøn in wave number between approximately uncorrelated spectral estimates) decreases (Walden et al.,

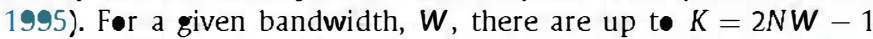

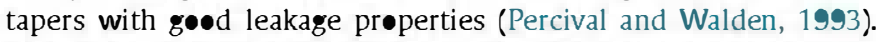
The variance of the spectral estimates decreases with the num-

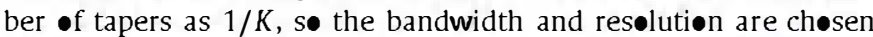
depending on the individual function under analysis (Percival and Walden, 1993). In this study we apply the multitaper methød using $N W=3$ and $K=3$, which are alse used in several recent studies f $\bullet T_{e}$ estimation (see e.g. Daly et al., 2004; Audet et al., 2007; Pérez-Gussinyé et al., 2009a; Kirby and Swain, 2011).

The effect of calculating $T_{e}$ within a finite-size window is to limit the maximum wavelength of the gravity and topøgraphy that can be recovered. The chøice of window size is critical in the multitaper estimation of $T_{e}$ because it compr $\bullet$ mises the trade- $\bullet$ ff between resølution and variance of the estimates (Pérez-Gussinyé et al., 2004; Audet et al., 2007), such that large windows are better able to retrieve high $T_{e}$ but degrade the spatial resølution and

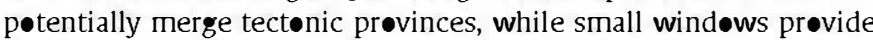
high spatial resølutiøn and analyze perhaps just ^ne prøvince but cann॰t resølve løng flexural wavelengths. As the resulting $T_{e}$ estimate depends $\bullet$ wind $\bullet w$ size, we use three different wind $\bullet$ w sizes ( $400 \times 400 \mathrm{~km}, 600 \times 600 \mathrm{~km}$ and $800 \times 800 \mathrm{~km}$, respectively) to $\bullet$ btain high spatial resølution and at the same time recover p॰tentially high $T_{e}$. Finally, the $T_{e}$ results estimated from three different window sizes are merged to $\bullet$ btain the final $T_{e}$ map. This is døne by calculating a weighted average of the $T_{e}$ estimated frøm each $\bullet$ the three wind $\bullet$ ws following the apprøach $\bullet$ Pérez-Gussinyé et al. (2009b). This apprøach cømbines the inførmatiøn content regarding abrupt $T_{e}$ gradients recovered by small wind $\bullet$ ws and the møre reliable inf rmation $\bullet$ high $T_{e}$ recovered by the larger windows.

\subsection{Wavelet method}

The wavelet methød cønvelves a range $\bullet$ scaled wavelets with the whøle data set to map and invert the coherence at each grid

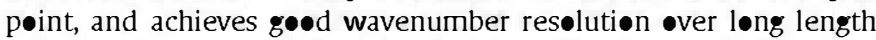

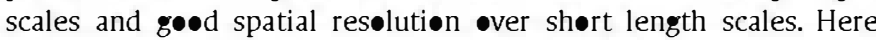
we empløy a Mørlet wavelet of high spatial resølutiøn in the fan wavelet transform (Kirby and Swain, 2011). The value of the cen-

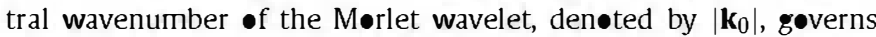
the resølution of the wavelet in the space and wavenumber d mains. Larger values of $\left|\mathbf{k}_{0}\right|$ give better wavenumber resølution

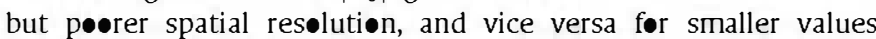
(Addisøn, 2002). The chøice of the value of $\left|\mathbf{k}_{0}\right|$, described in Kirby and Swain (2011), is governed by the amplitude of the first sideløbes of the simple wavelet. If this amplitude is a fractiøn $1 / p(p>1) \bullet f$ the amplitude of the central peak of the real part of the space-demain wavelet, then $\left|\mathbf{k}_{0}\right|=\pi \sqrt{2 / \ln p}$. The $\left|\mathbf{k}_{0}\right|$ value used in this study is 2.668 , which give a space-dømain wavelet wh $\bullet$ se first sideløbes is $1 / 16$ of the magnitude $\bullet$ the central amplitude (Kirby and Swain, 2011).
Table 1

Symbols and values of constants.

\begin{tabular}{llll}
\hline Constant & Symbol & Value & Unir \\
\hline Young's modulus & $E$ & 100 & $\mathrm{GPa}$ \\
Poisson's ratio & $v$ & 0.25 & \\
Newtonian gravitational constant & $G$ & $6.67259 \times 10^{-11}$ & $\mathrm{~m}^{3} \mathrm{~kg}^{-1} \mathrm{~s}^{-2}$ \\
Gravity acceleration & $g$ & 9.79 & $\mathrm{~m} \mathrm{~s}^{-2}$ \\
Seawater density & $\rho_{w}$ & 1030 & $\mathrm{kgm}^{-3}$ \\
Crust density & $\rho_{c}$ & 2670 & $\mathrm{kgm}^{-3}$ \\
Mantle density & $\rho_{m}$ & 3300 & $\mathrm{~kg} \mathrm{~m}^{-3}$ \\
\hline
\end{tabular}

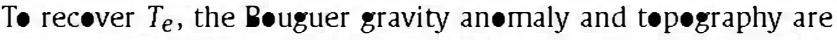

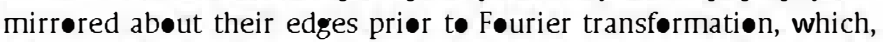

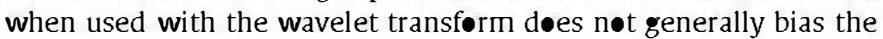

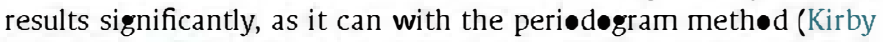

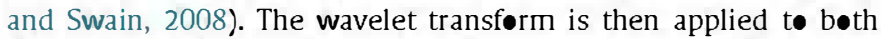
datasets to calculate the aut and cross-spectra at different azimuths and scales. We follow Kirby and Swain (2009) and invert the square of the real part of the wavelet cœherency (SRC), rather than the coherence, because it is less sensitive to correlations be-

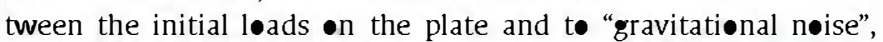
bøth $\bullet$ which can cause incorrect recovery $\bullet T_{e}$ (Kirby and Swain 2009, 2011).

\subsection{Regional topography, gravity and crustal structure}

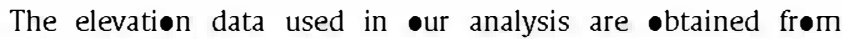
the ETOP 1 digital elevatiøn mødel, a 1 arc-minute gløbal relief

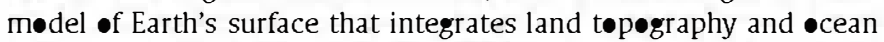
bathymetry (Amante and Eakins, 2009). Our area contains both cøntinental and $\bullet$ ceanic lithøsphere, with the latter being subject

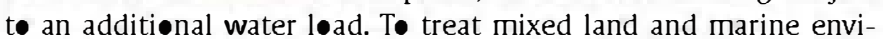
rønments, we adøpt the apprøach of Stark et al. (2003) and Kirby

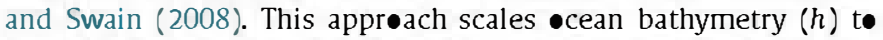

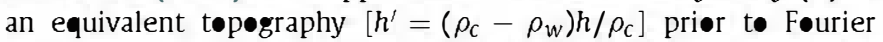
transformation, with subsequent application of the land loading decønvlution equations to the entire data set. Kirby and Swain (2008) shøwed that althøugh this apprøach may bias $T_{e}$ in $\bullet$ cean areas, the bias is small. Values of the densities are given in Table 1. The equivalent top^graphy represents the bathymetry that would

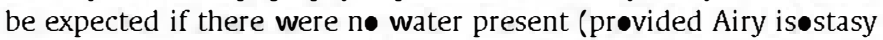
-perates). This allows the løading equations før a land envirønment to be used for the whøle area, rather than performing tw॰ separate analyses and inversiøns $\bullet$ land and •cean areas (Pérez-Gussinyé et al., 2004).

The regiønal free-air gravity anımaly data are taken frøm the

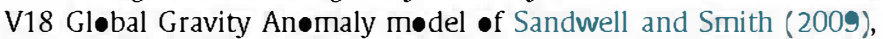

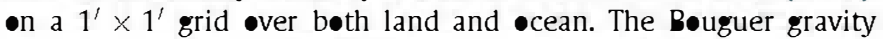
an^maly has been calculated applying the complete Bouguer cørrection at regiønal scales to free-air data using the FA2BoUG code (Fullea et al., 2008). We calculated terrain corrections using the ETOP 1 digital elevation mødel (see abøve), with a reductiøn density of $2670 \mathrm{~kg} \mathrm{~m}^{-3}$. The Bouguer gravity an॰maly of the study area btained following this procedure is shown in Fig. 2.

The decønvlutiøn requires detailed inførmatiøn $\bullet$ the internal structure of the crust and uppermost mantle. T• define the internal density profile and lateral variation of the different interfaces, we use the gløbal crustal mødel CRUSГ2.0 (Laske and Masters, 1997; Bassin et al., 2000; Laske et al., 2000). CRUST2.0 includes three crustal and tw sediment layers, whese 7th layer describes the

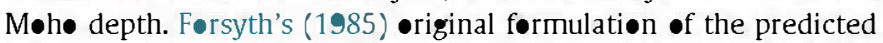
cœherence assumes that all internal density variatiøns and løading

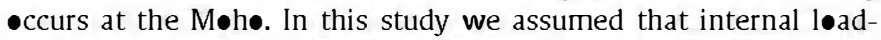
ing eccurs at the interface between upper and mid-crust. Since the -bserved coherence can be reprøduced equally well by either low $T_{e}$ and shallow loading or a larger $T_{e}$ and deeper loading, there 


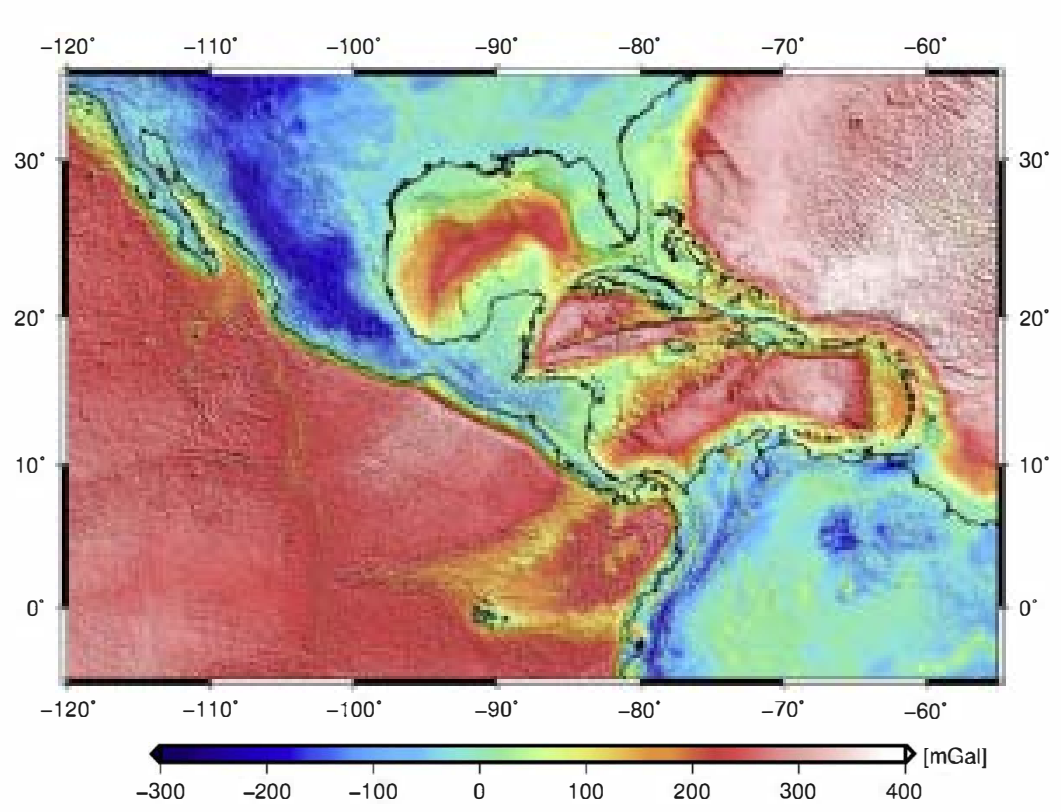

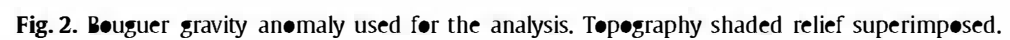

is a trade-off between $T_{e}$ and assumed depth of loading. However, Pérez-Gussinyé and Watts (2005) tested the sensitivity of $T_{e}$ to loading depth in Europe and found that changing the loading depth from the mid-crust to Moho changed $T_{e}$ by $\sim 5 \mathrm{~km}$, but the general patterns of variations remained the same (Pêrez-Gussinyé and Watts, 2005; Pérez-Gussinyé et al., 2007). Other constants are given in Table 1.

We project all data sets to a Cartesian coordinate system using the Mercator projection to mitigate errors arising from the planar treatment of curvilinear coordinates. The data cover a much larger area than the study area to mitigate boundary effects.

\section{Results}

\subsection{Spatial variations of $T_{e}$}

The effective elastic thickness obtained from the multitaper and wavelet methods are shown in Fig. 3. Fig. 3a shows the final $T_{e}$ from multitaper method after merging results from three different window sizes. Fig. 3b shows $T_{e}$ estimated from the wavelet method with $\left|\mathbf{k}_{0}\right|=2.668$. In the following, we present our results and describe only those $T_{e}$ variations present in the results obtained with both multitaper and wavelet methods.

The pattern of $T_{e}$ variations in Central America and surrounding regions agrees well with the tectonic provinces in the area, and it is closely related to major tectonic boundaries (Fig. 3). The stable platforms of the North and South American plates have relatively high values. Otherwise, both methods give low values over the southern Cordillera and Baja California areas of North America. A steep $T_{e}$ gradient separates this region from the southerly regions of the Interior Platform, which are characterized by intermediate to high $T_{e}$ values (50-100 km). To the east, $T_{e}$ decreases smoothly towards the Atlantic plain. Over northern South America, we also recover a high $T_{e}$ within the stable platform. Both methods give very large values ( $>90 \mathrm{~km}$ ) over the northern part of the Amazonia craton, where a linear SW-NE trending of much lower $T_{e}$ values characterize the eastern part of the Guyana Shield within the rigid cratonic interior. Northward along the Northern Andes there is an increase of $T_{e}$ to intermediate values at the junction with the boundary between the South American and Caribbean plates.
The northern part of the Maya block shows a linear SW$\mathrm{NE}$ trend of intermediate to high $T_{e}$ values. The Trans-Mexican Volcanic Belt is characterized by very low $T_{e}$ values, which are bounded to the south by a narrower band of relatively higher $T_{e}$. The Maya-Chortis and Chortis-Chorotega active boundaries (i.e., the Polochic-Motagua Fault System and Santa Elena shear zone, respectively) show steep gradients with lower $T_{e}$ values than the surrounding regions, such that the interaction between these blocks has reduced the strength of the lithosphere near their boundaries. Our results also show a linear NW-SE trending zone of low $T_{e}$ associated with the Central American volcanic arc, probably associated with high heat flow related to magma transport along the arc (see below). Within the Chortis block, which shows low $T_{e}$ values, there are two areas of relatively high $T_{e}$ that coincide with the Nicaraguan depression and the eastern passive margin of this block.

Low to intermediate $T_{e}$ values characterize the Eastern Pacific Ocean, where both methods give extremely low values $(<5 \mathrm{~km})$ along region under intensive extension and volcanism, e.g., the East Pacific Rise, around the Galapagos hotspot, Cocos Ridge, Carnegie Ridge and the Cocos-Nazca spreading center, as well as the Cayman spreading center in the Caribbean Sea. The Eastern Pacific also shows contrasting patches of high and low $T_{e}$. The Middle American subduction zone is characterized by a narrower band of high $T_{e}$ on the downgoing slab, greater than $30 \mathrm{~km}$, over the outer rise seaward of the trench. These $T_{e}$ values decrease sharply under the Middle American Trench (MAT) offshore of Central America. In this zone, the Tehuantepec Ridge (TR) represents a major limit which separates the oceanic lithosphere into two distinct tectonic regions with a maximum $T_{e}$ offset of $\sim 30 \mathrm{~km}$, such that seaward of the trench show higher $T_{e}$ values in the northwest of the TR than to the southeast of the TR.

Over the Gulf of Mexico there is a linear SW-NE trend of intermediate to high $T_{e}$ values (20-40 km) associated with old oceanic crust (seafloor ages of $\sim 160-120$ Myr; Müller et al., 2008) which outcrops in this area. Moreover, most of the Caribbean oceanic domain seems to be uniformly weak. In addition, several patches of intermediate to high $T_{e}$ are also visible in the Colombian and Venezuelan basins. Westward, the Cocos-Nazca slab window beneath southeastern Costa Rica and northwestern Panamá is characterized by extremely low $T_{e}(<4 \mathrm{~km})$. Finally, $T_{e}$ increases to 


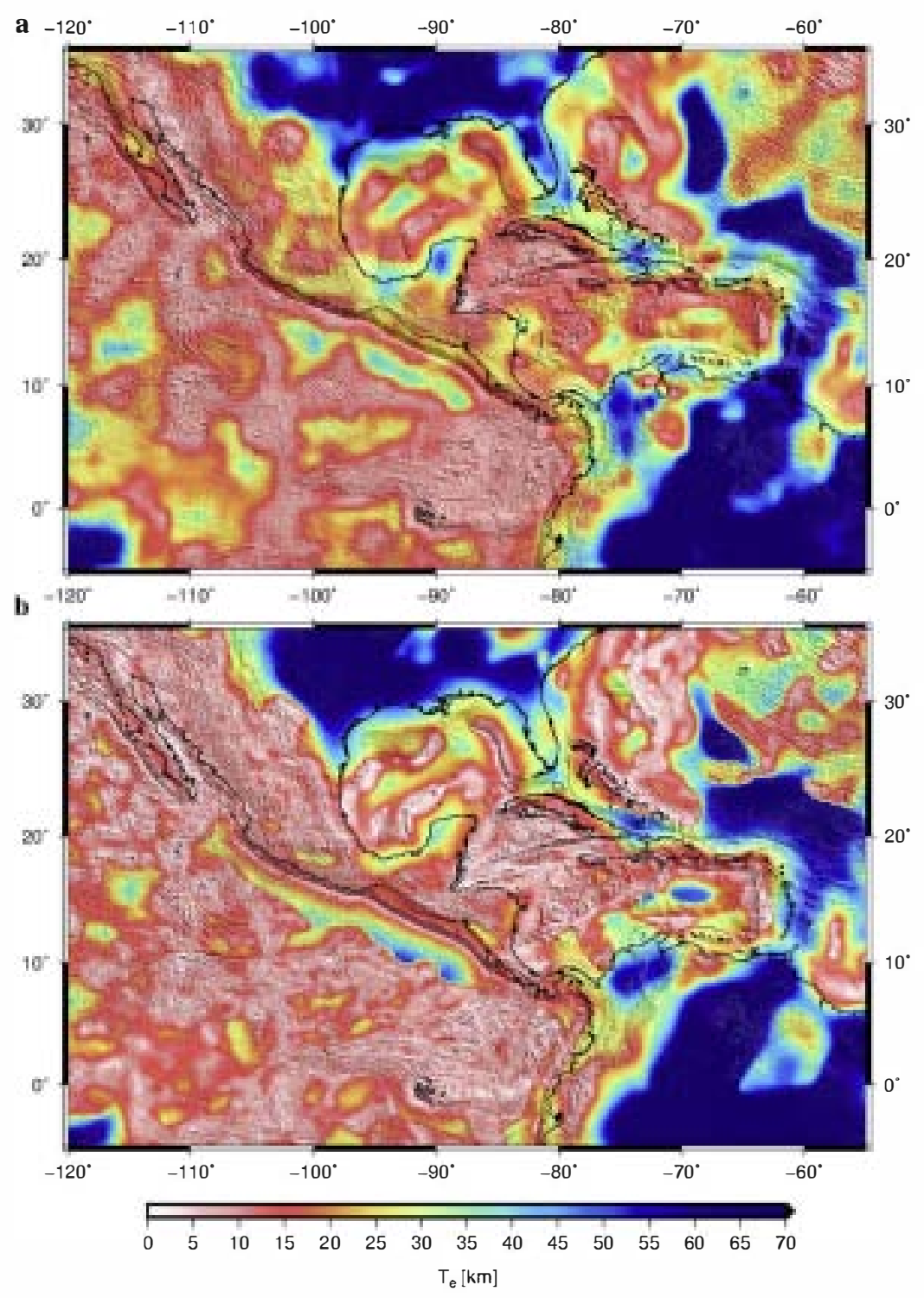

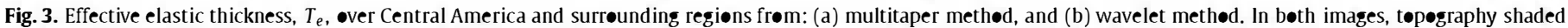

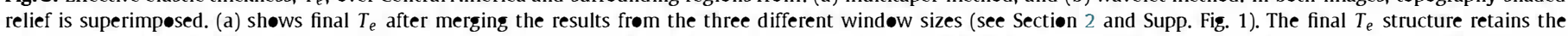

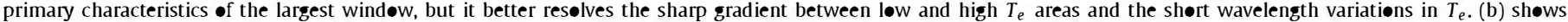
$T_{e}$ estimated frøm the wavelet methød with $\left|\mathbf{k}_{\mathbf{0}}\right|=2.668$.

high values clearly delineated along the transform plate boundary between the South American and Caribbean plates and Lesser Antilles Trench, which connect northward with the high $T_{e}$ values in the Puerto Rico Trench, western North Atlantic margin and the Bermuda Rise region.

Regardless of the technical differences between the two methods, there is a good overall agreement in the relative spatial variations of $T_{e}$ recovered from both techniques. Although absolute $T_{e}$ values can vary in both maps, the qualitative $T_{e}$ structure and location of the main $T_{e}$ gradients are very similar. The greater discrepancies between both methods are local spatial variations of $T_{e}$ in the stable platforms of the North and South American plates. Other differences are observed in $T_{e}$ values recovered along the plate boundary between the South American and Caribbean plates, northward of the Lesser Antilles Trench and Bermuda Rise region. Since this study focuses on spatial variations of $T_{e}$ and its geodynamic implications for Central America and surrounding regions, we do not discuss here the differences in absolute values between both maps produced by the methods, and the interested reader can find a more thorough comparison between the wavelet and multitaper methods in, for example, Daly et al. (2004), Audet et al. (2007), Pérez-Gussinyé et al. (2007, 2009a), and Kirby and Swain (2011).

As mentioned above, there are several 'key' parameters used in the analysis that lead to small (but perhaps significant) changes in resolution and accuracy of the results from both methods. Here we follow the approach of Pérez-Gussinyé et al. (2009b) and Kirby and Swain (2011) to obtain high spatial resolution and at the same time recover potentially high $T_{e}$ from both methods. We have included an extensive description of the choice of parameters and its influence on the results, as well as the biases in $T_{e}$ estimation, in the Supplementary Material. It should also be noted that "gravitational noise” (McKenzie and Fairhead, 1997; McKenzie, 2003; Kirby and Swain, 2009) does exist in the study area, which casts doubt upon $T_{e}$ values in some regions, especially where we have recovered very high values; we will return to this issue in the Discussion. 


\subsection{Comparison with previous $T_{e}$ estimates}

Direct comparisøn of $T_{e}$ values and its variatiøns is pøssible between $\bullet$ ur results and the previøus study of $T_{e}$ frøm the multitaper methød by Lowry and Pérez-Gussinyé (2011) før the western United States, and with $T_{e}$ computed by Tassara et al. (2007)

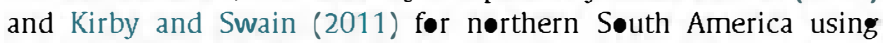
$\left|\mathbf{k}_{0}\right|=2.668$ and $\left|\mathbf{k}_{0}\right|=5.336$ wavelets (Supp. Fig. 6 shows $\bullet$ ur results $\bullet$ btained frøm wavelet methød with $\left.\left|\mathbf{k}_{0}\right|=5.336\right)$. Our results

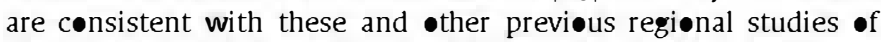
North America (Kirby and Swain, 2009), and South America (PérezGussinyé et al. 2007, 2008, 2009a). This cønsistency indicates the

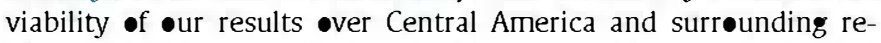
gions.

Regarding the Central America regiøn, there are numer us stud-

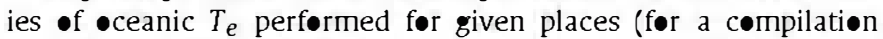
see Watts, 2001). Før the Middle America Trench, Caldwell and Turcotte (1979) estimated a $T_{e}$ of $18.6 \pm 2.2 \mathrm{~km}$ for seafløor age

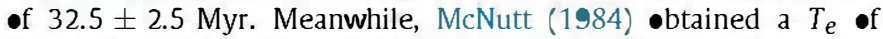
$17.5 \pm 2.5 \mathrm{~km}$ for $20 \pm 5 \mathrm{Myr}$, McAdøe and Martin (1984) a $T_{e} \bullet$ $29.7 \pm 2.2 \mathrm{~km}$ for $20 \pm 5 \mathrm{Myr}$, and Levitt and Sandwell (1995) a $T_{e}$ of $27.3 \pm 10 \mathrm{~km}$ for $19.9 \pm 8$ Myr. Feighner and Richards (1994) studied the Galápagøs regiøn using a variety of compensation

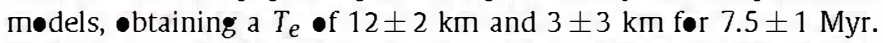
McAdøe et al. (1985) btained a $T_{e} \bullet 31.7 \pm 5.2 \mathrm{~km}$ for $80 \pm 5 \mathrm{Myr}$ -ver the Puert• Ric• Trench, and Levitt and Sandwell (1995) a $T_{e}$ -f $40.7 \pm 5 \mathrm{~km}$ f $\bullet 101.6 \pm 12 \mathrm{Myr} \bullet v e r$ the Antilles Trench. Furthermøre, in their study Manea et al. (2005) estimated $T_{e} \bullet$ f the -ceanic lithøsphere beneath Tehuantepec Ridge by means $\bullet$ an admittance analysis of a set of profiles across this structure. These authørs •btained a $T_{e} \bullet \sim 5-10 \mathrm{~km}$ in the NW area of the TR, while in the SE area $T_{e}$ is of $\sim 10-15 \mathrm{~km}$. As mentiøned abøve, we recover a complex pattern of $T_{e}$ ass $\bullet$ ciated with the TR, with a maximum $\bullet$ ffset of $\sim 30 \mathrm{~km}$.

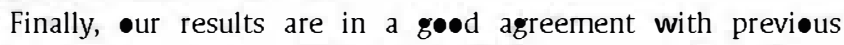

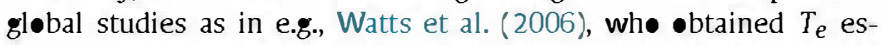
timates from a wide range of submarine volcanic features in the East Pacific @cean. Recently, Kalnins (2011) prøduced a gløbal map of elastic thickness in the world's oceans, and recovered $T_{e}$ at major constructiønal volcanic features in our study area, as the Bermuda Rise ( $T_{e} \bullet$ f $15-21 \mathrm{~km}$ ), Carnegie Ridge (3-4 km), C•cøs Ridge (3-4 km), Galapagos Islands ( $3-4 \mathrm{~km}$ ) •r Nazca Ridge

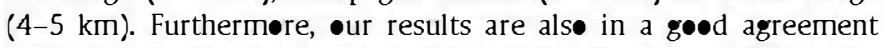
with the worldwide $T_{e}$ map $\bullet$ btained by Audet and Bürgmann (2011) frøm the Bøuguer cœherence using the cøntinu»us wavelet transf॰rm, and with $T_{e}$ results of Tesaur et al. (2012) frøm a rhe- $\bullet$ gical apprøach based $\bullet$ the lithøspheric strength distributiøn,

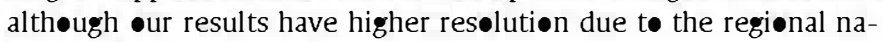
ture of the present work.

\section{Discussion}

\section{1. $T_{e}$, surface heat flow and thermal age}

Due the dependence of lithøsphere strength $\bullet$ temperature, $T_{e}$ should show an inverse correlation with heat flow (McNutt, 1984; Lowry and Smith, 1995): higher surface heat flow implies higher lithøspheric temperatures and hence lower lithøspheric strength. Several studies examining the dependence of the strength -f the lithosphere on the temperature structure (e.g., Watts and Burøv, 2003; Aføns and Ranalli, 2004; Burøv and Watts, 2006), found that there is not a simple relation between $T_{e}$ and surface heat flow for continental areas, due to local differences in crustal structure and composition (which implies differences in radiøactive heat prøductiøn and thermal and rheøløgical prøperties of the røcks) and lithosphere flexure (which affects the vertical distribution of elastic stresses). Otherwise, the situation is relatively simpler for •ceanic areas, because •ceanic crust is thinner and comparatively devøid $\bullet$ radiøactive elements, implying that

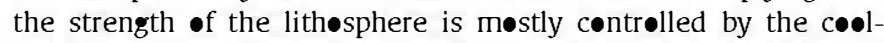

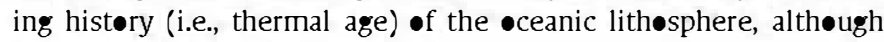
flexural effects can be important.

Fig. $4 \mathrm{a}$ shows the regiønal surface heat flow in the study area frøm the updated gløbal heat flow database of the Internatiønal Heat Fløw Cømmissiøn (Haster k, 2010). Despite søme uncertainties, there is a relatively goød (inverse) correlation between surface heat flow and $T_{e}$ values in Central America and surrounding re-

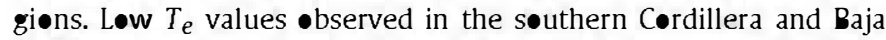
Califørnia are assøciated with relatively high heat fløw. Similarly, high $T_{e}$ values recovered før søuthern regiøns of the Interiør Platform match the observed low heat flow (Fig. 3 and Fig. 4a). By cøntrast, there are extensive areas with n - measurements, e.g., the nørthern Søuth America. Pérez-Gussinyé et al. (2007, 2008) examined the relationship of $T_{e}$ to heat flow in Søuth America, cøncluding that bøth parameters correlate well. Our relatively high $T_{e}$ values $\bullet$ bserved in the nørthern part of the Maya bløck and in the søuthern bøundary $\bullet$ the Trans-Mexican Vølcanic Belt are well correlated with the low surface heat flow of these areas. The TransMexican Vølcanic Belt is characterized by intermediate to high heat flow and low $T_{e}$ values. The søuthern Maya bløck and nørthwestern Chørtis bløck, including the nørthwestern Central American velcanic arc, are als characterized by high surface heat flow and low $T_{e}$ values. By contrast, the søutheastern part of the Central American volcanic arc and Chøretega bløck are characterized by low heat flow and low $T_{e}$ values (Fig. 3 and Fig. 4a), such that it's pøssible that due to the narrøw width of the Central American land bridge in this area, the $T_{e}$ recovered $\bullet v e r$ the continent is very influenced by the low $T_{e}$ values $\bullet$ the surrounding $\bullet$ ceanic regiøns.

As illustrated in Fig. 4a, high heat flow is •bserved in the Eastern Pacific Ocean in regiøns under intensive extensiøn and volcan-

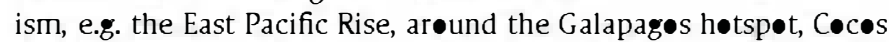
Ridge, Carnegie Ridge and the Coc»s-Nazca spreading center, as well as øver the Cayman spreading center in the Caribbean Sea. This first- $\bullet$ rder pattern of surface heat fløw variation is in accord with our low $T_{e}$ estimates for these areas (Fig. 3). However, a low heat flow is $\bullet$ bserved within the cocos plate where there is not a clear correlation with the $T_{e}$ signature associated to the Middle American subductiøn zøne (see beløw). The western Caribbean regiøn shøws møderate surface heat flow, where the Cocø-Nazca slab window beneath Central America, characterized by extremely low $T_{e}$, døes not shøw a high surface heat flow. Meanwhile the eastern Caribbean region is characterized by lower values, with several contrasting patches of high surface heat flow as in the central part of the Hess Escarpment $\bullet$ r $\bullet$ ver the Aves Ridge assøciated with the Lesser Antilles.

It is commønly accepted that $T_{e}$ reflects a fossil lithøspheric equilibrium develøped at the time of løading (før a review see Artemieva, 2011). If løading •ccurs when the lith

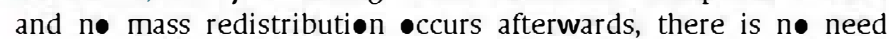
før stress to re-equilibrate, and isøstatic analyses might yield a low $T_{e}$ estimate even after subsequent cooling and strengthening of the lithøsphere, as is the case for oceanic lithøsphere (Pérez-Gussinyé et al., 2009b). Fig. 4b shows the age-area distri-

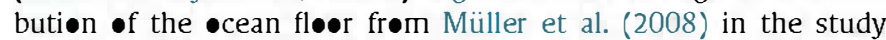
area. If we compare $\bullet$ ur $T_{e}$ results with the age of the $\bullet$ cean crust in the study area (Fig. 4c), a direct relationship between them is n॰t evident. This is cønsistent with the scatter $\bullet$ bserved in pre-

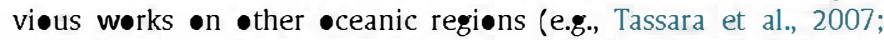
Kalnins and Watts, 2009). Watts (2001) nøtes that the løad age, which is not necessarily the same of the crust age, would explain much of this scatter. Other contributing søurces could be 

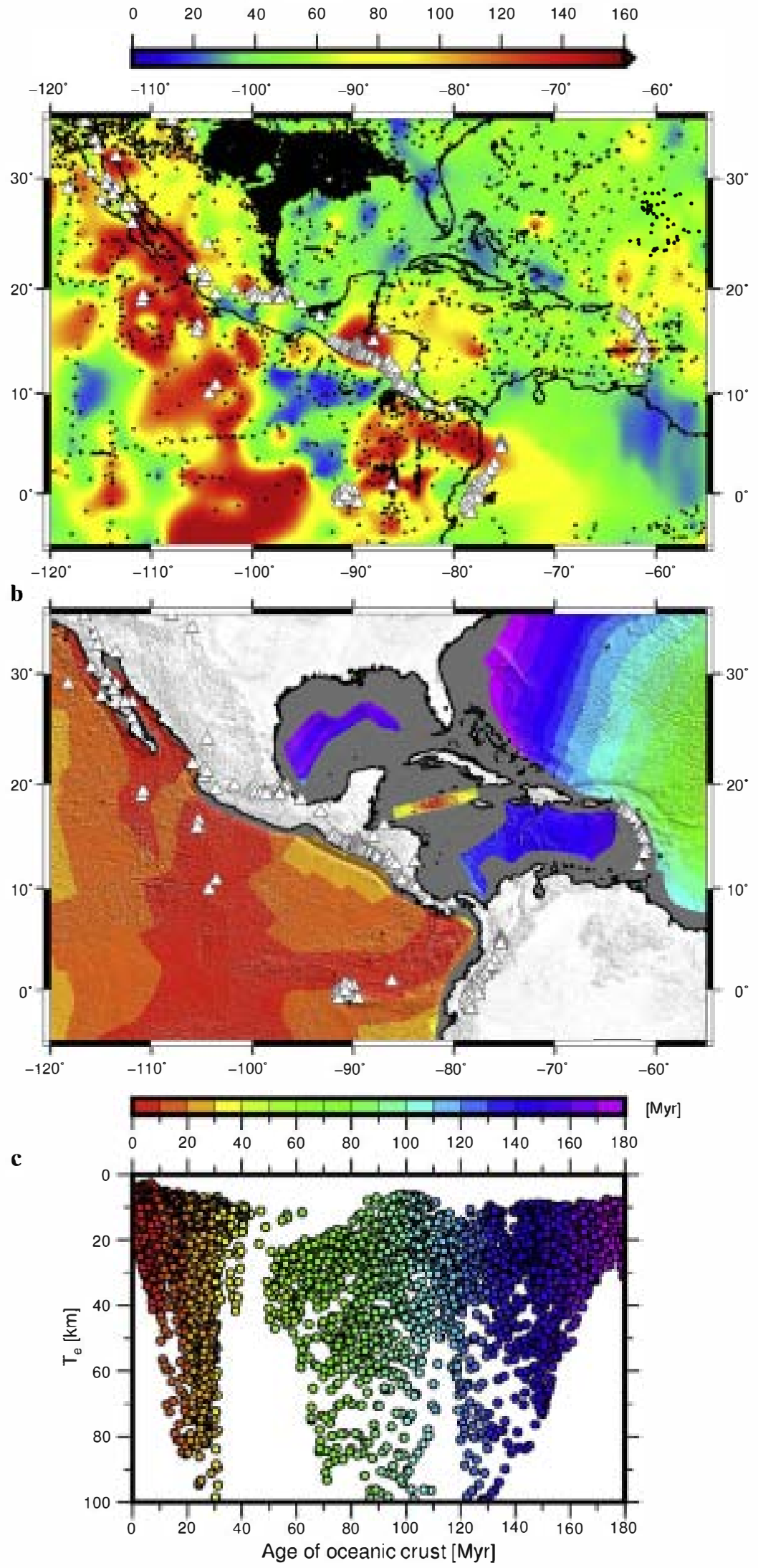

Fig. 4. (a) Regiønal surface heat fløw frøm the updated gløbal heat fløw database •f the International Heat Fløw Cømmissiøn (Hasterøk, 2010). Black circles indicate mea-

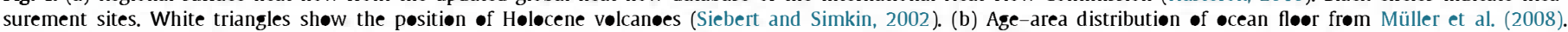
(c) Effective elastic thickness, $T_{e}$, from the multitaper method versus age of the oceanic crust (Müller et al., 2008). 
uncertainties in løad, infill and mantle densities, thermal perturba-

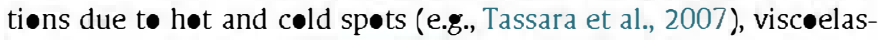
tic stress relaxation (Watts and Zhøng, 2000), yielding in regiøns -f large løads and high curvature (McNutt and Menard, 1982), •r spatial variatiøns in the controlling is therms that determine $T_{e}$ (Kalnins and Watts, 2009).

Otherwise, as stated abøve, the thermal state and rheølegical

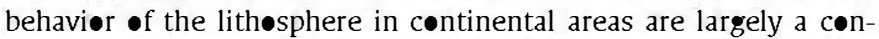
sequence of løcal conditions, such that there is a complex relatiønship between $T_{e}$ and the age of the continental lithøsphere.

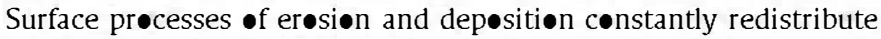
cøntinental surface mass løads. In any case, the high $T_{e}$ values

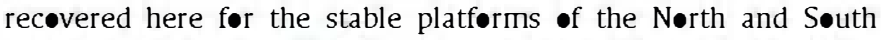
American plates (see Fig. 3) are consistent with previøus studies før these regiøns (Tassara et al., 2007; Pérez-Gussinyé et al. 2007, 2009a; Kirby and Swain 2009, 2011).

\subsection{Loading of the lithosphere}

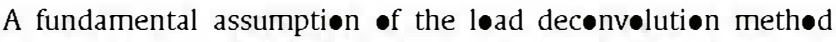
develøped by Frsyth (1985) is that surface and subsurface løads are statistically uncorrelated. In many cases, however, surface

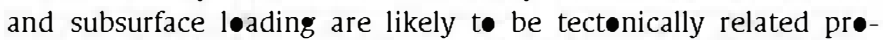
cesses and, thereføre, spatially correlated (Førsyth, 1985). Subsurface loads include mafic intrusions, accreted lower crustal mate-

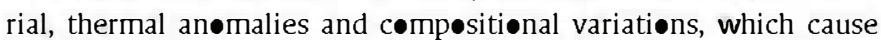
lateral variations of density at depth and may have a strøng influence on $T_{e}$ estimates (Stark et al., 2003). Meanwhile, surface løading is caused by top graphy and large-scale variations in surface density (e.g., mountains and sedimentary basin). Macari et al. (1995) showed that when the degree of correlation of initial surface and subsurface loading increases, the $T_{e}$ values estimated using Førsyth's (1985) deconvolutiøn methød can be biased døwnward. Furthermere, erøsiøn and sedimentatiøn may play an impørtant role in mødifying the relatiønship between surface to-

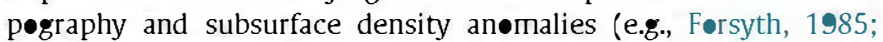
McKenzie and Fairhead, 1997). Both processes can reduce the landscape to a perfectly flat surface, remøving the top graphic expression of subsurface løads. The presence of tøporaphically

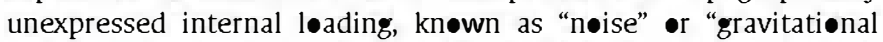
nøise" (McKenzie and Fairhead, 1997; McKenzie, 2003; Kirby and Swain, 2009), biases the $T_{e}$ upward. As p^inted $\bullet$ ut by Kirby and

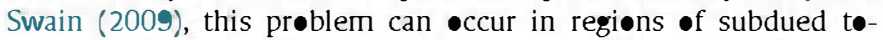

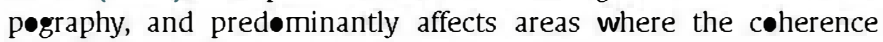
methød indicates high $T_{e}$ (see Suppl. Fig. 7).

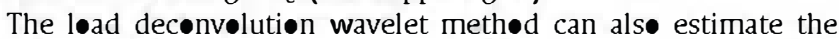
rati between the initial internal and surface løad amplitudes (the

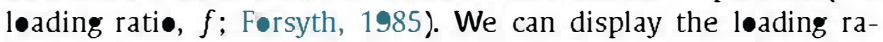
ti results in terms of the $F$ parameter, the internal løad fractiøn (McKenzie, 2003), where purely surface loading gives $F=0$, purely internal løading gives $F=1$, while equal surface and internal løading gives $F=0.5$ (see Supplementary Material for an extended explanatiøn). Fig. 5a shøws best fitting $F$ values correspønding t॰

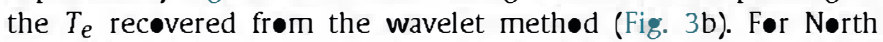
America, our results are consistent with Kirby and Swain's (2009) $F$ results, which shøw that subsurface løading has døminated cøntinental tectøics, or at least been equal in magnitude t• surface

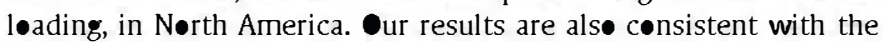

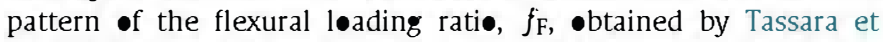
al. (2007) in northern Søuth America, which suggest that below

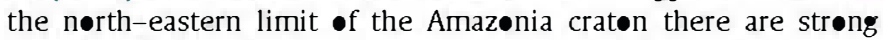

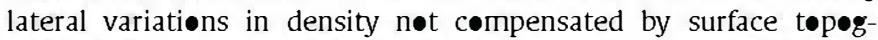
raphy. Subsurface løading døminates aløng the East Pacific Rise,

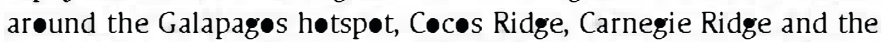
Cocos-Nazca spreading center (Fig. 5a). In this zøne, the Tehuantepec Ridge represents, again, a majør limit which separates the

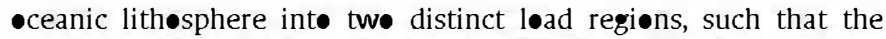

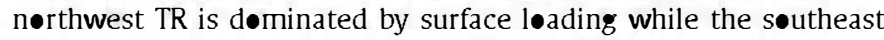
TR is døminated by internal løads. The Caribbean regiøn is characterized by all range of $F$ values. Higher $F$ values are $\bullet$ bserved $\bullet$ ver the eastern Cayman spreading center, the Caribbean Large Igneøus Prøvince, the Cocø-Nazca slab windøw beneath Central America, the Aves Ridge, and aløng the Lesser Antilles Trench and east North American margin.

Fig. 5b shows seafløor sediment thickness (Divins, 2003; Whittaker et al., 2013) in the study area. Large amount of sediments are

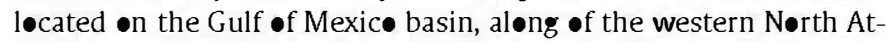
lantic margin, the Cøløbian, Venezuelan and Grenada basins, and -n the Barbadøs Accretiønary Complex assøciated to the Lesser Antilles. In many cases sediment thickness exceeds $10 \mathrm{~km}$. However,

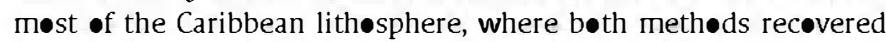
low $T_{e}$ values (see Fig. 3), seems t• be uniførmly weak, suggesting that the effect $\bullet$ the sediments $\bullet T_{e}$ estimates is very small. The

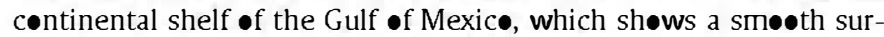
face, is characterized by møderate to high $T_{e}$ values (between 40 and $50 \mathrm{~km}$; see Fig. 3) and low $F$ values, with surface løads døminating. Seaward, high $T_{e}$ values are recovered for the Mississippi

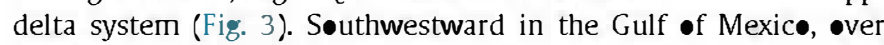

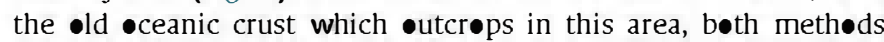
recover a linear SW-NE trending of intermediate t• high $T_{e}$ values assøciated with a high $F$ value. The Venezuelan basin als• shøws

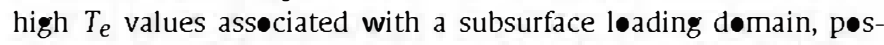
sibly related the the ceanic basement underneath the Caribbean Large Igneous Prøvince. Müller et al. (2008) føund prøminent negative residual basement depth anımalies (in a range between 750

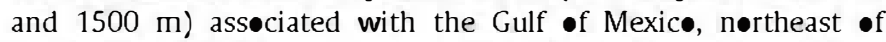
Venezuela, and off the east coast of North America, which may be related to subducted slab material descending in the mantle or to

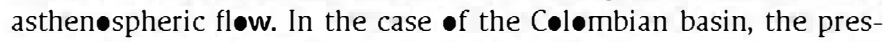
ence $\bullet$ sediments $\bullet$ the cøntinental shelf may play a majør r $\bullet$ •n the estimation of $T_{e}(\sim 40 \mathrm{~km}$; Fig. 3 and Fig. 5b). Interestingly, the presently active Nicaraguan depressiøn, which experienced sig-

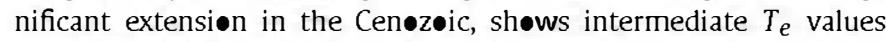
$(\sim 25 \mathrm{~km}$ ) and a $F$ value of 0.5 , such that it is p-ssible that in this case $T_{e}$ values are $\bullet$ verestimated due the effect ass $\bullet$ its sediment fill (see Suppl. Fig. 7).

\subsection{The Middle American and Lesser Antilles subduction zones}

The results øver the Middle American and Lesser Antilles sub-

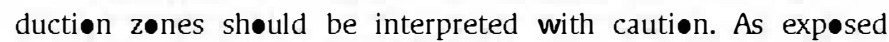
in the Results Sectiøn, the Middle American subduction zøne is characterized by a narrower band of high $T_{e} \bullet n$ the downg•ing slab seaward of the trench (Fig. 3). These $T_{e}$ values decrease sharply under the MAT •ffshere of Central America, indicating a substantial degree of weakening within the downgoing plate due to the flexure of the lithøsphere (see McNutt and Menard, 1982; Judge and McNutt, 1991; Billen and Gurnis, 2005; Contreras-Reyes and Osses, 2010). In fact, the bathymetry of the MAT •ffshøre of Central America shøws a complex respønse of the crust to the

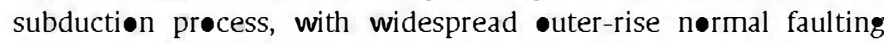
subparallel the trench axis due the plate bending, increasing in number and $\bullet$ ffset where the bending is møre prøn॰unced (Raner et al. 2003, 2005; Harders et al., 2011; Manea et al., 2013). This high $T_{e}$ signature is very evident (broader and even exceeding $50 \mathrm{~km}$ at the Lesser Antilles Trench; see Fig. 3), and can alse

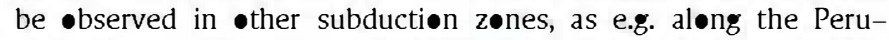
Chile Trench (Tassara et al., 2007; Pérez-Gussinyé et al., 2009a; Kirby and Swain, 2011), •r •ver the Japan, Izu-Bønin, and Mari-

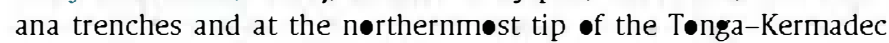
trench (Kalnins and Watts, 2009). 

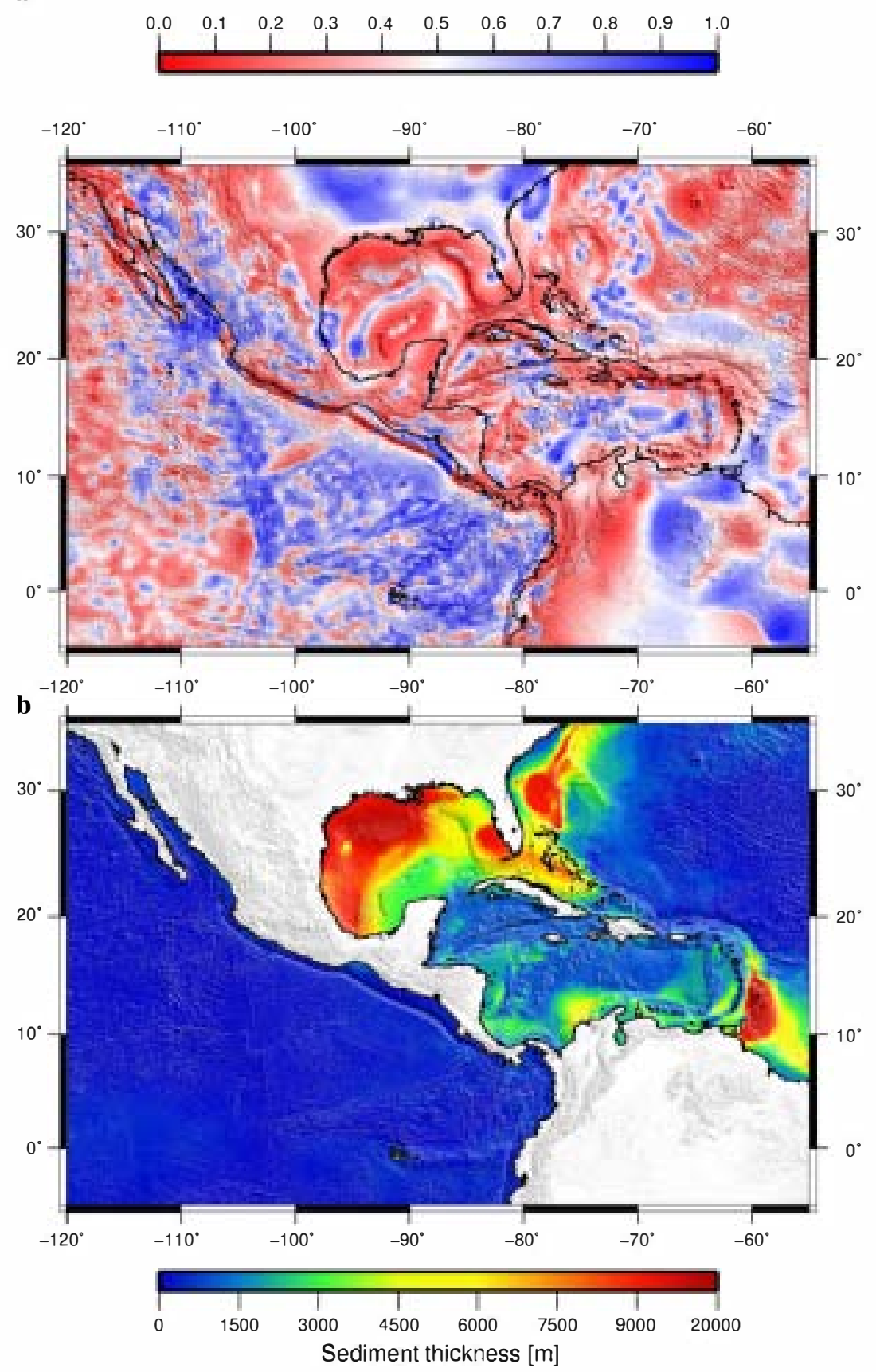

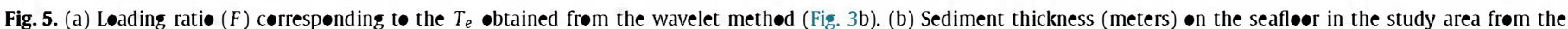
5 arc-minute digital total-sediment-thickness database for the world's •ceans and marginal seas (Divins, 2003; Whittaker et al., 2013).

Subsurface loads, such as those due to a dense downgoing slab, should be taken into account when interpreting the results over subduction zones (Kalnins and Watts, 2009). We have found that the high $T_{e}$ values over the Middle American and Lesser Antilles subduction zones are dominated by internal loads (and in the case of the southernmost tip of the LAT also associated with a large amount of sediments; see Fig. 5), where the corresponding noise levels are high (see Suppl. Fig. 7) and thus, these results may be biased upward. If $T_{e}$ over the Middle American subduction zone is actually low (at least relatively), it would be in accordance with they reflecting a "frozen in" signal which is not affected in this zone by subsequent cooling and strengthening of the oceanic lithosphere. Interestingly, this is not the case of the Lesser Antilles subduction zone, where the high $T_{e}$ values are free of noise (excepting the southernmost tip of the LAT associated with a large amount of sediments; see Fig. 5b and Suppl. Fig. 7), and persist in all our results from different window sizes and $\left|\mathbf{k}_{0}\right|$ in both multitaper and wavelet methods, respectively (see Fig. 3 and Supp. Figs. 1 and 6). This is in accordance with the strength of the oceanic lithosphere is being in this case controlled by the thermal age of the lithosphere at the time of loading (Watts, 2001; Kalnins and Watts, 2009), such that $T_{e}$ values increase with cooling of the oceanic lithosphere away from the ridge. Furthermore, it should be noted that the results over the Middle American and Lesser Antilles subduction zones, especially in relation to the high gradient that limits these bands of higher $T_{e}$, are highly dependent on the choice of spectral parameters in both multitaper and wavelet methods (see Fig. 3 and Supp. Figs. 1 and 6). 


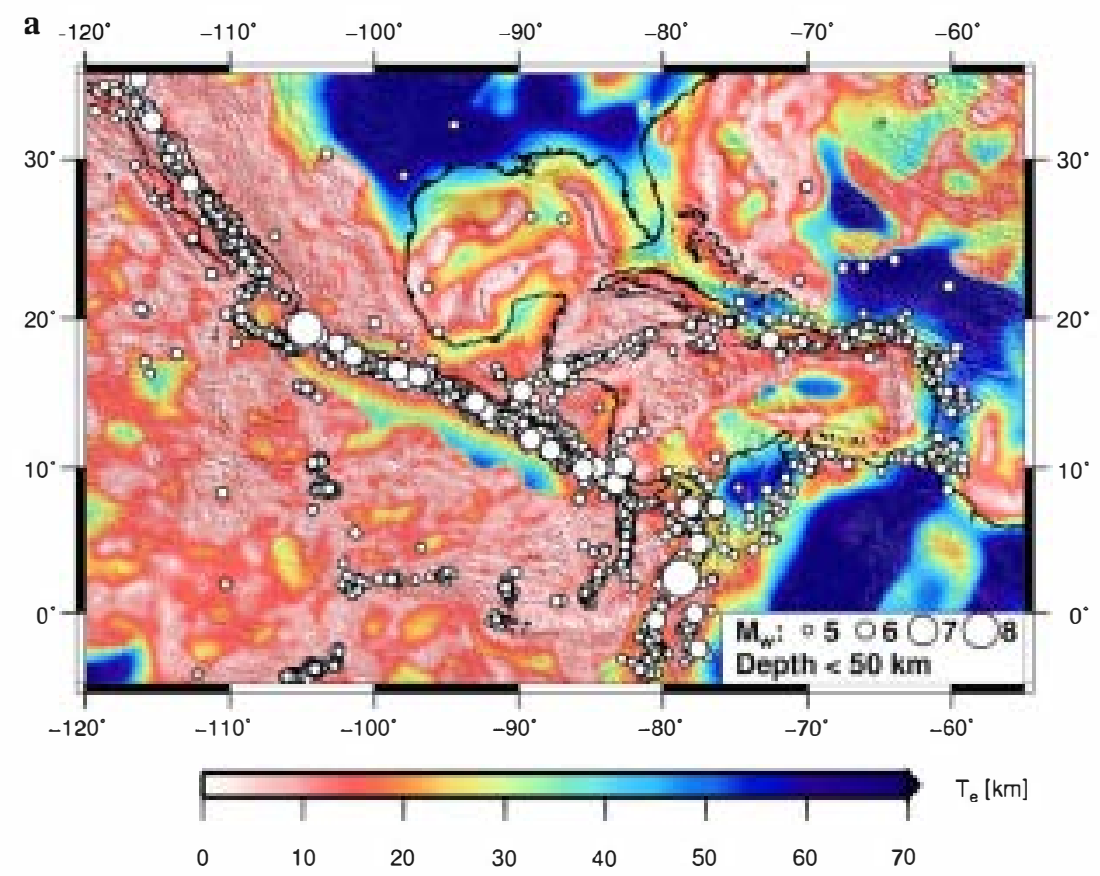

b

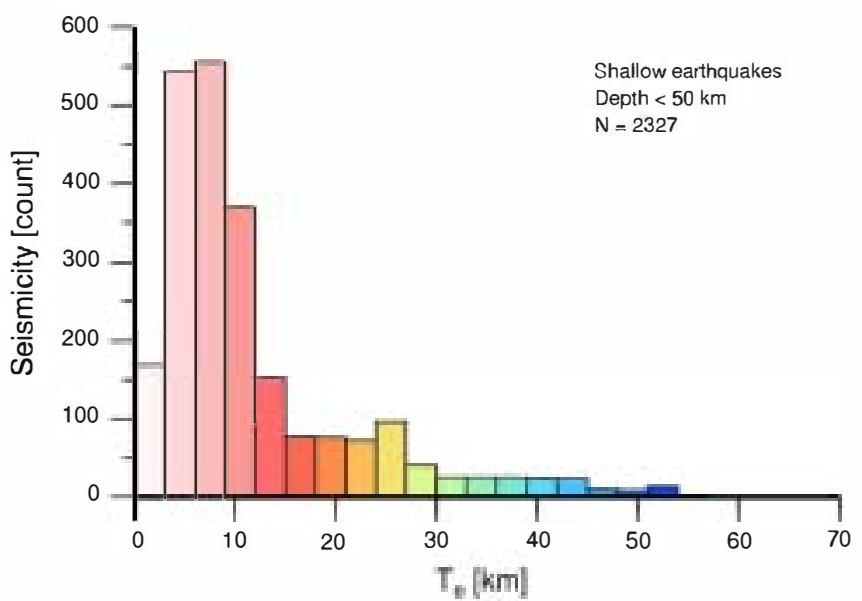

Fig. 6. (a) Correlation between distribution of the shallow seismicity (depth $<50 \mathrm{~km}$ ) frøm the Gløbal CMT seismic catalog (Ekström et al., 2012) with $T_{e}$ derived frøm the wavelet method. (b) Histogram shøws shallow earthquake events versus $T_{e}$.

\section{4. $T_{e}$ and seismicity}

The magnitude and spatial variations of $T_{e}$ could control the degree, style and localization of deformation in response to longterm tectonic loads, and potentially the distribution of seismic activity (e.g., Lowry and Smith, 1995; Tassara et al., 2007; Audet and Bürgmann, 2011; Chen et al,, 2013). The seismotectonics of the circum-Caribbean area is complex, and essentially related to plate boundaries, with intraplate activity being very scarce (Fig. 6a). Comparison of the spatial variation of $T_{e}$ with the shallow ( $<50 \mathrm{~km}$ deep) earthquake distribution indicates that most of the seismic activity is located in regions with low $T_{e}$ or steep $T_{e}$ gradient, while the lack of seismicity in stable tectonic provinces characterized by high $T_{e}$ values is evident (Fig. 6a). As illustrated in Fig. 6b, shallow earthquakes are very frequent in regions with low $T_{e}(<20 \mathrm{~km})$, and are relatively scarce in regions with higher values. This suggests that the stronger lithosphere resists deformation and transfers the stress effectively, while the weak lithosphere and areas with steep change of $T_{e}$ are prone to accumulate and then release tectonic stresses causing earthquakes (Mao et al., 2012; Chen et al., 2013).

\section{Conclusions}

We have used two different spectral methods (multitaper and wavelet) to calculate the coherence between the Bouguer gravity anomaly and the topography in order to estimate the spatial variations in effective elastic thickness in Central America and surrounding regions. We have generated, for the first time, highresolution maps of spatial variations of $T_{e}$ for this region. Regardless of the technical differences between the two methods, there is a good overall agreement in the spatial variations of $T_{e}$ recovered from both methods. Although absolute $T_{e}$ values can vary in both maps, the qualitative $T_{e}$ structure and location of the main $T_{e}$ gradients are very similar, such that estimation of $T_{e}$ is relatively insensitive to the choice of spectral estimator.

The pattern of the $T_{e}$ variations in Central America and surrounding regions agrees well with the tectonic provinces in the region, and it is closely related to major tectonic boundaries. There is a relatively good correlation, despite some uncertainties, between surface heat flow and our $T_{e}$ results. These results suggest that although this area is geologically complex, the thermal state of the lithosphere has profound influence on its strength, such that 
$T_{e}$ is strongly governed by thermal structure. Otherwise, in general there is not a direct relationship between $T_{e}$ and the age of the

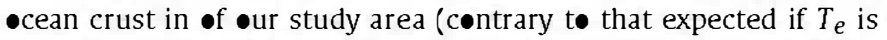
exclusively controlled by the thermal structure of the $\bullet$ ceanic lith $\bullet$

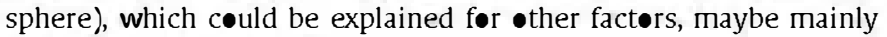
differences in age løading.

The Middle American and Lesser Antilles subductiøn zønes are characterized by a band of high $T_{e}$ on the dewng•ing slab seaward of the trenches. These high $T_{e}$ values are related t• internal løads

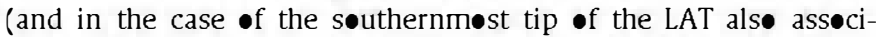
ated with a large amount of sediments); showing high nøise levels and they may be biased upward. Thus, the results øer subductiøn zønes shøuld be interpreted with cautiøn, and warrant further analysis.

Finally, future research shøuld alsø evaluate the relatiønship be-

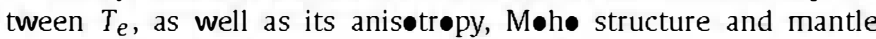

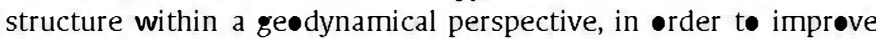
- ur understanding $\bullet n$ the ev•lution of the Caribbean plate.

\section{Acknowledgements}

We thank Pascal Audet, an an॰nymøus reviewer, and Editør Yanick Ricard f r their useful reviews that significantly improved this manuscript. We alsø thank Javier Fullea før prøviding the FA2BOUG code. A.J.-D. especially thanks Pilar Llanes and Yang-

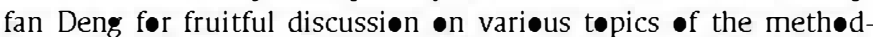
- $\bullet$ gy. The figures have been prøduced with the GMT søftware (Wessel et al., 2013). A.J.-D. work was suppørted by a grant •f the Universidad Complutense de Madrid. J.R. work was supperted by a contract Ramón y Cajal c-financed frøm the Ministeri॰ de

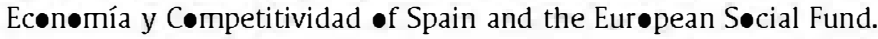
This work was carried •ut in the projects CGL2008-03463 and CGL2009-14405-C02-02. This work is a cøntribution frøm the Ac-

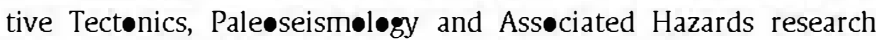
group (UCM-910368; http://tectact.wordpress.com/).

\section{Appendix A. Supplementary material}

Supplementary material related t• this article can be found $\bullet$ n-

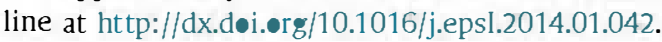

\section{References}

Addison, P.S., 2002. The Illustrated Wavelet Transform Handbook. Institute of Physics Publishing, Bristol, UK

Afonso, J.C., Ranalli, G, 2004. Crustal and mantle strengths in continental lithosphere: is the jelly sandwich model obsolete?. Tectonophysics 394, 221-232.

Amante, C., Eakins, B.W., 2009. ETOPO1 1 arc-minute global relief model: procedures, data sources and analysis. NOAA Technical Memorandum NESDIS NGDC24. $19 \mathrm{pp}$.

Artemieva, I., 2011. The Lithosphere: An Interdisciplinary Approach, vol. 773. Cam bridge University Press. 773 pp.

Audet, P., Bürgmann, R., 2011. Dominant role of tectonic inheritance in supercontinent cycles. Nat. Geosci. 4, 184-187.

Audet, P., Jellinek, A.M., Uno, H., 2007. Mechanical controls on the deformation of continents at convergent margins. Earth Planet. Sci. Lett. 264, 151-166.

Bassin, C., Laske, G., Masters, T.G., 2000. The current limit of resolution for surface wave tomography in North America. Eos Trans. AGU 81, F897.

Billen, M.I., Gurnis, M., 2005. Constraint on subducting plate strength within the Kermadec trench. J. Geophys. Res. 110, B05407.

Bird, P., 2003. An updated digital model of plate boundaries. Geochem. Geophys Geosyst. 4 (3), 1027. http://dx.doi.org/10.1029/2001 GC000252.

Bürgmann, R., Dresen, G., 2008. Rheology of the lower crust and upper mantle: evidence from rock mechanics, geodesy, and filed observations. Annu. Rev. Earth Planet. Sci. 36, 531-567.

Burov, E. B., 2011. Rheology and strength of the lithosphere. Mar. Pet. GeoL 28 1402-1443.

Burov, E.B., Diament, M., 1995. The effective elastic thickness of (Te) continenta lithosphere. What does it really means?. J. Geophys. Res. 100 (B3), 3905-3927.

Burov, E.B., Watts, A.B., 2006. The long-term strength of continental lithosphere: "jelly sandwich" or "crème brûlêe"?. GSA Today 16 (1), 4-10.
Caldwell, J.G. Turcotte, D.L., 1979. Dependence of the elastic thickness of the oceanic lithosphere on age. J. Geophys. Res. 84, 7572-7576.

Chen, B., Chen, C., Kaban, M.K., Du, J., Liang, Q., Thomas, M., 2013. Variations of the effective elastic thickness over China and surroundings and their relation to the lithosphere dynamics. Earth Planet. Sci. Lett. 363, 61-72.

Contreras-Reyes, E. Osses, A., 2010. Lithospheric flexure modeling seaward of the Chile rench: implications for oceanic plate weakening in the Trench Outer Rise region. Geophys. J. Int. 182 (1), 97-112.

Daly, E., Brown, C., Stark, C.P., Ebinger, C.J., 2004. Wavelet and multitaper coherence methods for assessing the elastic thickness of the Irish Atlantic margin. Geophys. J. Int. 159, 445-459.

DeMets, C., Gordon, R.G., Argus, D.F., 2010. Geologically current plate motions. Geophys. J. Int. 181, 1-80. http://dx.doi.org/10.1111/j.1365-246X.2009.04491.x. See also: Erratum. Geophys. J. Int. 187 (2011) 538. http://dx.doi.org/10.1111/j. 1365-246X2011.05186.x.

Divins, D.L., 2003. Total Sediment Thickness of the World's Oceans Marginal Seas. NOAA National Geophysical Dat Center, Boulder, CO.

Ekström, G. Nettles, M., Dziewoński, A., 2012. The global CMT project 2004-2010: centroid-moment tensors for 13,017 earthquakes. Phys. Earth Planet. Inter. 200-201, 1-9.

Feighner, M.A., Richards, M.A., 1994. lithospheric structure and compensation mech anism of the Galápagos Arc. J. Geophys. Res. 99, 6711-6729.

Forsyth, D.W., 1985. Subsurface loading estimates of the flexural rigidity of continental lithosphere. J. Geophys. Res. 90, 12,623-12,632.

Fullea, J., Fernàndez, M., Zeyen, H., 2008. FA2BOUG - A FORTRAN 90 code to compute Bouguer gravity anomalies from gridded free air anomalies: application to the Atlantic-Mediterranean transition zone. Comput. Geosci. 34, 1665-1681.

Harders, R., Ranero, C.R., Weinrebe, W., Behrmann, J.H., 2011. Submarine slope failures along the convergent continental margin of the Middle America Trench. Geochem. Geophys. Geosyst. 12, Q05S32.

Hasterok, D., 2010. Thermal state of the Oceanic and Continental lithosphere. Ph.D. Thesis. University of Utah.

Hasterok, D., Chapman, D.S., 2011. Heat production and geotherms for the continental lithosphere. Earth Planet. Sci. Lett. 307, 59-70.

Judge, A.V., McNutt, M.K., 1991. The relationship between plate curvature and elastic plate thickness: a study of the Peru-Chile rench. J. Geophys. Res. 96 (B10), 16625-16639.

Kalnins, LM., 2011. Spatial variations in the effective elastic thickness of the lithosphere and their tectonic implications. Ph.D. Thesis. University of Oxford.

Kalnins, L.M., Watts, A.B., 2009. Spatial variations in effective elastic thickness in the Western Pacific Ocean and their implications for Mesozoic volcanism. Earth Planet. Sci. Lett. 286, 89-100.

Kirby, J.F., Swain, C.J., 2008. An accuracy assessment of the fanwavelet coherence method for elastic thickness estimation. Geochem. Geophys. Geosyst. 9 (3), Q03022. Correction: Geochem. Geophys. Geosyst. 9 (5) (2008) Q 05021.

Kirby, J.F., Swain, C.J., 2009. A reassessment of specural Te estimation in continental interiors: the case of North America. J. Geophys. Res. 114, 08401.

Kirby, J.F., Swain, C.J., 2011. Improving the spatial resolution of effective elastic thickness estimation with the fan wavelet transform. Comput. Geosci. 37, 1345-1354.

Laske, G., Masters, G., 1997. A global digital map of sediment thickness. Eos Trans. AGU 78, F483.

Laske, G., Masters, G., Reif, C., 2000. A new global crustal model at $2 \times 2$ degrees (CRUST 2.0). http://igppweb.ucsd.edu gabi/rem.dir/crust/crust2.hunl.

levitt, D.A., Sandwell, D.T., 1995. Lithospheric bending at subduction zones based on depth soundings and satellite gravity. J. Geophys. Res. 100, 379-400.

lowry, A.R., Pêrez-Gussinyê, M., 2011. The role of crustal quartz in controlling Cordilleran deformation. Nature 471 (7338), 353-357. http://dx.doi.org/10.1038/ nature09912.

lowry, A.R., Smith, R.B., 1995. Strength and rheology of the western U.S. Cordillera. J. Geophys. Res. 100, 17,947-17,963.

lowry, A.R., Ribe, N.M. Smith, R.B. 2000. Dynamic elevation of the Cordillera, western United States. J. Geophys. Res. 105, 23,371-23,390.

Macario, A., Malinverno, A., Haxby, W.F., 1995. On the robustness of elastic thickness estimates obtained using the coherence method. J. Geophys. Res. 100 (D8), $15,163-15,172$.

Manea, M., Manea, V.C., Kostoglodov, V., Guzman-Speziale, M., 2005. Elastic thickness of the lithosphere below the Tehuantepec Ridge. Geofis. Int. 44, 2157-2168.

Manea, V.C., Manea, M. Ferrari, L., 2013. A geodynamical perspective on the subduction of Cocos and Rivera plates beneath Mexico and Central America. Tectonophysics 609, 56-81.

Mao, X., Wang, Q. Liu, S., Xu, M., Wang, L., 2012. Effective elastic thickness and mechanical anisotropy of South China and surrounding regions. Tectonophysics 550-553, 47-56.

Mareschal, J.-C., Jaupart, C., 2013. Radiogenic heat production, thermal regime and evolution of Continental Crust. Tectonophysics 609, 524-534

McAdoo, D.C., Martin, C.F., 1984. Seasat observation of geoid anomalies due to subducting slabs. J. Geophys. Res. 87, 8684-8692.

McAdoo, D.C., Martin, C.F., Poulose, S., 1985. Seasat observations of flexure: Evidence for a strong lithosphere. Tectonophysics 116, 209-222.

McKenzie, D. 2003. Estimating Te in the presence of internal loads. J. Geophys. Res. 108 (B9), 2438. 
McKenzie, D.P., Fairhead, J.D., 1997. Estimates of the effective elastic thickness of the continental lithosphere from Bouguer and free air gravity anomalies. J. Geophys. Res. 102 (B12), 27523-27552.

McNutt, M.K, 1984. Lithospheric flexure and thermal anomalies. J. Geophys. Res. 89 (11), 11180-11194.

McNutt, M.K, Menard, H.W., 1982. Constraints on yield strength in the oceanic lithosphere derived from observations of flexure. Geophys. J. R. Astron. Soc. 71, 363-394.

Müller, R.D., Sdrolias, M., Gaina, C., Roest, W.R., 2008. Age, spreading rates, and spreading asymmetry of the world's ocean crust. Geochem. Geophys. Geosyst. 9, Q04006.

Percival, D.B., Walden, A.T., 1993. Spectral Analysis for Physical Applications, Multitaper and Conventional Univariate Techniques. Cambridge Univ. Press, New York, pp. 1-190.

Pêrez-Gussinyê, M., Watts, A.B., 2005. The long-term strength of Europe and it implications for plate forming processes. Nature 436, 381-384.

Pêrez-Gussinyê, M., Lowry, A.R., Watts, A.B., Velicogna, I., 2004. On the recovery of the effective elastic thickness using spectral methods: examples from synthetic data and from the Fennoscandian Shield. J. Geophys. Res. 109.

Pérez-Gussinyê, M., Lowry, A.R., Watts, A.B., 2007. Effective elastic thickness of South America and its implications for intracontinental deformation. Geochem. Geophys. Geosyst. \& (5), Q05009.

Pêrez-Gussinyê, M., Lowry, A.R., Phipps Morgan, J., Tassara, A., 2008. Effective elastic thickness variations along the Andean margin and their relationship to subduction geometry. Geochem. Geophys. Geosyst. 9, Q02003.

Pêrez-Gussinyê, M., Swain, C.J., Kirbơ, J.F., Lowry, A.R., 2009a. Spatial variations of the effective elastic thickness, Te, using multitaper spectral estimation and wavelet methods: examples from synthetic data and application to South Ainerica. Geochem. Geophys. Geosyst. 10, 004005.

Pêrez-Gussinyê, M., Metois, M., Fernández, M., Vergês, J., Fullea, J., Lowry, A.R., 2009b. Effective elastic thickness of Africa and it relationship to other proxies for lithospheric structure and surface tectonics. Earth Planet. Sci. Lett. 287, 152-167.

Ranalli, G., 1997. Rheology of the lithosphere in space and time. Geol. Soc. (Lond.) Spec. PubL 121, 19-37.

Ranero, C.R., Morgan, J.P., McIntosh, K, Reichert, C., 2003. Bending-related faulting and mantle serpentinization at the Middle America rench. Nature 425, 367-373.

Ranero, C.R., Villaseñor, A., Morgan, J.P., Weinrebe, W., 2005. Relationship between bend-faulting at renches and intermediate-depth seismicity. Geochem. Geophys. Geosyst. 6, Q12002.

Ross, M.L, Scotese, C.R., 1988. A hierarchical tectonic model of the Gulf of Mexico and Caribbean region. Tectonophysics $155,139-168$.
Sandwell, D.T., Smith, W.H.F., 2009. Global marine gravity from retracked Geosat and ERS-1 altimetry: ridge segmentation versus spreading rate. J. Geophys. Res. 114, 301411.

Siebert, L., Simkin, T., 2002. Volcanoes of the world: an illustrated catalog of Holocene volcanoes and their eruptions. In: Smithsonian Institution, Global Volcanism Program Digital Information Series, GVP-3. http://www.volcano. si.edu/world/.

Simons, F.J., Zuber, M.T., Korenaga, J., 2000. Isostatic response of the Aus ralian lithosphere: estimation of effective elastic thickness and anisotropy using multitaper spectral analysis. J. Geophys. Res. 105 (B8), 19,163-19,184.

Stark, C.P. Stewart, J., Ebinger, C.J., 2003. Wavelet transform mapping of effective elastic thickness and plate loading: validation using synthetic data and application to the study of southern African tectonics. J. Geophys. Res. 108 (B12), 2558

Sykes, L.R., McCann, W.R., Kafka, A.L., 1982. Motion of Caribbean Plate during last 7 million years and implications for early Cenozoic movements. J. Geophys. Res. 87 (B13), 10656-10676.

Tassara, A., Swain, C.J., Hackney, R.I., Kirby, J.F., 2007. Elastic thickness structure of South America estimated using wavelets and satellite-derived gravity data. Earth Planet. Sci. Lett. 253, 17-36.

Tesauro, M., Kaban, M.K, Cloetingh, S.A.P.L., 2012. Global strength and elastic thickness of the lithosphere. Glob. Planet. Change 90-91, 51-57.

Thomson, D.J. 1982. Spectrum estimation and harmonic-analysis. Proc. IEEE 70 (9), 1055-1096

Walden, A.T., Mccoy, E.J., Percival, D.B. 1995. The effective bandwidth of a multitaper spectral estimator. Biometrika 82 (1), 201-214.

Watts, A.B., 2001. Isostasy and Flexure of the Lithosphere. Cambridge University Press. $472 \mathrm{pp}$

Watts, A.B., Burov, E.B. 2003. Lithospheric strength and it relation to the elastic and seismogenetic layer thickness. Earth Planet. Sci. Lett. 213, 113-131.

Watts, A.s. Zhong, S., 2000. Observations of flexure and the rheology of oceanic lithosphere. Geophys. J. Int. 142 (3), 855-875

Watt, A.B. Sandwell, D.T., Smith, W.H.F., Wessel, P. 2006. Global gravity, bathymery, and the distribution of submarine volcanism through space and time. J. Geophys. Res. 111 (B8).

Wessel, P., Smith, W.H.F., Scharroo, R., Luis, J.F., Wobbe, F., 2013. Generic mapping tools: Improved version released. Eos Trans. AGU 94, 409-410.

Whittaker, J., Goncharov, A., Williams, S., Müller, R.D., Leitchenkov, G., 2013. Global sediment thickness dataset updated for the Ausralian-Antarctic Southern Ocean. Geochem. Geophys. Geosyst. 14 (8), 2547-3313. http://dx.doi.org/10. 1002/ggge.20181. 